\begin{tabular}{|l|l|l|}
\hline \multicolumn{2}{|c|}{ PublisherInfo } \\
\hline \hline PublisherName & $:$ & BioMed Central \\
\hline \hline PublisherLocation & $:$ & London \\
\hline \hline PublisherImprintName & $:$ & BioMed Central \\
\hline \hline
\end{tabular}

\title{
GI toxicity of celecoxib vs traditional NSAIDs
}

\begin{tabular}{|l|l|l||}
\hline \multicolumn{2}{|c|}{ ArticleInfo } \\
\hline \hline ArticleID & $:$ & 133 \\
\hline \hline ArticleDOI & $:$ & $10.1186 /$ ar-2000-66863 \\
\hline \hline ArticleCitationID & $:$ & 66863 \\
\hline \hline ArticleSequenceNumber & $:$ & 90 \\
\hline \hline ArticleCategory & $:$ & Paper Report \\
\hline \hline ArticleFirstPage & $:$ & 1 \\
\hline \hline ArticleLastPage & $:$ & 3 \\
\hline \hline & & RegistrationDate : 2000-11-7 \\
\hline ArticleHistory & $:$ & OnlineDate \\
\hline \hline ArticleCopyright & $:$ & Current Science Ltd2000-11-7 \\
\hline \hline ArticleGrants & $:$ & \\
\hline \hline ArticleContext & $:$ & 130753311 \\
\hline \hline
\end{tabular}


Affl Washington University School of Medicine, St Louis, Missouri, USA

\title{
Keywords
}

\author{
COX-2, coxibs, NSAID GI toxicity
}

\section{Context}

The discovery of a second isoform of the cyclooxygenase enzyme, COX-2, led to the recognition that COX-2 is primarily responsible for mediating pain and inflammation, whereas COX-1 provides for gastric protection and other homeostatic functions. Selective inhibitors of COX-2 (coxibs) were developed based on the hypothesis that such agents could reduce inflammation and pain with less gastrointestinal (GI) toxicity than nonselective traditional nonsteroidal antiinflammatory drugs (NSAIDs). This study tests that hypothesis in patients with rheumatoid arthritis and osteoarthritis.

\section{Significant findings}

The annual incidence of symptomatic ulcers and ulcer complications (bleeding, perforation, and obstruction) was less in patients taking celecoxib $400 \mathrm{mg}$ twice daily $(0.44 \%)$ than in patients taking ibuprofen $800 \mathrm{mg}$ three times a day or diclofenac $75 \mathrm{mg}$ twice daily (1.27\%), so long as they were not taking aspirin. In patients taking low-dose aspirin (up to $325 \mathrm{mg} /$ day), the occurrence of adverse GI events was lower with celecoxib than with nonselective NSAIDs, although this difference did not achieve statistical significance.

\section{Comments}

This study confirms the hypothesis that selective inhibition of COX-2 is associated with a reduction in serious GI toxicity, and demonstrates that this benefit is lost with co-administration of aspirin, an inhibitor of COX-1. The duration of therapy for analysis was limited to 6 months because of a high patient drop-out rate (43\%). The fact that celecoxib therapy did not eliminate GI toxicity suggests a mechanism of toxicity unrelated to prostaglandin inhibition (such as Helicobacter pylori), or the 
possibility that COX-2 inhibition may itself cause some GI toxicity, and that the COX-1/COX-2 paradigm is an oversimplification.

\section{Methods}

Prospective, randomized controlled trial with active comparator

\section{References}

1. Silverstein FE, Faich G, Goldstein JL, Simon LS, Pincus T, Whelton A, Makuch R, Eisen G, Agrawal NM, Stenson WF, Burr AM, Zhao WW, Kent JD, Lefkowith JB, Verburg KM, Geis GS:

Gastrointestinal toxicity with celecoxib vs nonsteroidal anti-inflammatory drugs for osteoarthritis and rheumatoid arthritis. JAMA. 2000, 284: 1247-1255.

This PDF file was created after publication. 